\title{
Etiology and Causative Pathogens of Febrile Neonates
}

\section{Lida Bulbul ${ }^{1}$, Ali Bulbul2 ${ }^{*}$, Seda Ocak ${ }^{2}$, Umut Zubarioglu², Mine Cengiz ${ }^{2}$, Sinan Uslu ${ }^{2}$, Evrim Kiray Bas ${ }^{2}$ and Gizem Kara Elitok ${ }^{2}$}

${ }^{1}$ Department of Pediatrics, Bakırköy Dr. SadiKonuk Educational and Research Hospital, Istanbul, Turkey

${ }^{2}$ Division of Neonatology, Department of Pediatrics, University of Health Sciences, Sisli Hamidiye Etfal Educational and Research Hospital, Istanbul, Turkey

*Corresponding author: Ali Bulbul, Associate Professor, Division of Neonatology, Department of Pediatrics, University of Health Sciences, Sisli Hamidiye Et fal Educational and Research Hospital Istanbul, Turkey, Fax: +90 212234 11 21; Tel: +90 505 2654425; E-mail: drbulbul@yahoo.com

Received date: February 13, 2018; Accepted date: February 20, 2018; Published date: February 22, 2018

Citation: Bulbul L, Bulbul A, Ocak S, Zubarioglu U, Cengiz M, et al. (2018) Etiology and causative pathogens of febrile neonates. Pediatric Infect Dis Vol.3, No.1:5.

Copyright: (C2018 Bulbul L, et al. This is an open-access article distributed under the terms of the Creative Commons Attribution License, which permits unrestricted use, distribution, and reproduction in any medium, provided the original author and source are credited.

\section{Abstract}

Background: Evaluation and treatment of febrile neonates varied widely among the different centers. The prevalence of serious bacterial infection (SBI) is high in neonates; thus, most experts would support the approach of a full sepsis evaluation and hospitalization. We aimed to evaluate the clinical and laboratory characteristics of febrile neonate less than 28 days of age and describe the incidence of SBI in febrile neonates.

Methods: This prospective observational cohort study was include neonates with a rectal temperature of $\geq 38^{\circ} \mathrm{C}$ who admitted to NICU between 2011 and 2015. Demographic information, physical examination findings, laboratory test results, and final diagnosis were recorded and compared to identifiedas serious bacterial infection (SBI) or no-SBI. For determination of SBI; CRP and WBC cut-off values were calculated by receiver operating characteristic curve analysis.

Results: 328 infants were included the study. The overall rate of SBI was $38.4 \%$. The common final diagnosis were found unknown reason (43.6\%), urinary tract infection $(15.5 \%)$, dehydration (14\%), and bacteremia (5.8\%). The most common bacterial growth in culture Escherichia coli in 19 cases and Methicillin-Resistant Coagulase-Negative Staphylococci in 16 cases detected. A significant cut-off value could not be determined for CRP (AUC: 0.664 ) $95 \% \mathrm{Cl}$ : 0.604-0.723 and WBC (AUC: 0.535) 95\% Cl: 0.472-0.597.

Conclusion: Gram positive pathogens were more common in febrile neonates than older febrile infants. A reliable cutoff value for CRP and WBC for detection SBI in neonatal period could not be determined.

Keywords: Fever; Newborn; Pathogen; Urinary tract infection

\section{Introduction}

Fever is not uncommon in neonatal period, and the incidence rate of fever was documented as 14.4/1000 full tem births [1]. Although such fevers are typically self-limiting, it has been reported that $7.1-19.7 \%$ of affected neonate also have serious bacterial infection (SBI) [2-5]. Febrileinfants younger than $\leq 28$ days are at higher risk of serious bacterial infections (SBI), traditionally, so they need to go through laboratory investigation and hospitalization due to increased susceptibilityto infections.

But in some cases origin of fever is not an infection or other serious diseases. Therefore large numbers of febrile neonates continue to receive unnecessary treatment that generates emotional stress to parents, costsand may be associated with iatrogenic complications and antibiotic resistance [2-6]. Rochester and Philadelphia protocols can be used for identification of Serious bacterial infections in older infants, but in neonatal period sensitivity of these protocols are low [7]. For this reason, it is reported that C-reactive protein (CRP), absolute neutrophil count and procalcitonin levels can be used in SBI determination in the first month of life [6-9]. Somestudies reported that the contribution of White blood cells count (WBC) in the identification of $\mathrm{SBI}$ is very low; thus,importance should be givenon CRP level over absolute neutrophil count and absolute band counts and WBC [4-10].

Firstly the objective of present study was to evaluate clinical and laboratory characteristics of febrile neonates and describe the etiology and causative organisms in febrile neonates. Secondary find out the cutoff value of the serum levels of CRP and WBC for predicting SBI.

\section{Method}

The study was a prospective observational cohort study conducted at a tertiary care university-affiliated medical center in Istanbul. The study protocol was approved by the local ethic committee. Written informed consent was obtainedfrom the parents of all infants enrolled in thestudy before inclusion. 


\section{Study population}

Between January 2011 and December 2015 (5 years), all neonates who were admitted to the neonatal intensive care unit with a rectal temperature of $\geq 38^{\circ} \mathrm{C}$ (documented at the time of medical evaluation) wereeligible for the participation in this study. Gestational age $\leq 35$ weeks, who refused to participate in the study, chromosome abnormality, the presence of a chronic disease, congenital malformations, admission to pediatric surgery, and incomplete records were excluded from study. A complete historywas obtained from the parents of infants, and a specialist in neonatology carried out a physical examination for localizing the source of the feverin all infants.

\section{Data collection}

The data obtained for all infants included: demographic information (age at admission, gender, and birthweight), general assessment (well or sick-appearing), medical history, physical examination findings, laboratory test results, and final diagnosis. Laboratory investigations including complete blood count, CRP level, blood chemistry and culture, urine sample analysis and culture (obtained by bladder catheterization), and cerebrospinal fluid sample analysisand culture, were carried out. In the presence of respiratory symptoms or signs, chest radiography was performed. Lumbar puncture was performed according tothe ward's policy, which is required for every infant if neurologic findings are positive or without thefocus on fever Stool specimens were obtained when a history of diarrhea was noted and sent for white blood cell analysis and bacterial culture. Other tests were conducted as necessary. Skin, soft tissue, and ear infections were diagnosed by physical examination.

\section{Definition of SBI}

SBI was defined as (1) the growth of a known pathogenic bacteria in one or more of cultures, (2) any disease commonly associated with bacterial pathogens including pneumonia, acute otitis media, suppurative arthritis, osteomyelitis, and soft-tissue infections (mastitis, omphalitis). Pneumonia was defined as a new discrete infiltration on the chest film, which was confirmed by an attending pediatric radiologist with the presence of typical clinical signs and symptoms.
All specimens for culture were evaluated by standard microbiological methods. No specimens were processed for viral cultures. The blood culture isolates were consideredpathogenic if the organism was known to cause disease in healthy infants. UTI (urinary tract infection) was defined as the isolation of $>10^{4}$ $\mathrm{CFU} / \mathrm{mL}$ of urine ofa single pathogen by catheterization. A positive urine analysis was defined by a positive test for leucocyte esterase or nitrite by the dipstick method or leukocyte $\geq 10$ cells $/ \mathrm{mm}^{3}$ in uncentrifuged urine.

Methods of viral agent evaluation: in infants with viral respiratory symptoms and complaints (a runny nose, sneezing, coughing), the presence of RSV-Ag (rapid immunochromatographic test produced by Prima lab SA, Switzerland), and influenza-Ag (Immunoassay test produced by Dalian Rongbang Medical Healthy Devices, Spain) were assessed from nasopharyngeal secretions. The body weight of the subjects was takenon admission and weight loss was assessed according to the birth weight. The proportion of weight loss more than twelve percent of birth weightwas considered as dehydration.

All patients were hospitalized and prophylactic antibiotic therapy was started and continued for at least $72 \mathrm{~h}$ (cases diagnosed only with dehydration did not receive antibiotics).

\section{Statistical analysis}

The data were analyzed by using SPSS version 15.0 (SPSS, Chicago, IL, USA). Categorical variables are reported as percentages, and normally distributed data are expressed as mean \pm SD. Statistical comparisons between positive SBI group and negative SBI group performed withStudent's t-test for normally distributed data, Mann-Whitney $U$ test for nonnormally distributed data, and chi-square test for all numerical and categorical values. For predicting SBI, the serum levels of CRP and WBC count were subjectedto receiver operating characteristics (ROC) curve analysis. The results were considered to be significant if analysis yielded $p<0.05$.

\section{Results}

During the study, a total of 328 infants met the inclusion criteria. The diagram of study present in figure 1 . Table 1 shows the characteristics of newborns in the study.

Table 1: Demographic characteristics of 328 neonates with fever included in the study

\begin{tabular}{|l|l|l|}
\hline & Mean \pm Standard deviation & Lower-upperlimits \\
\hline Gender, $\mathrm{n}(\%)$ Male & $184(56.1)$ \\
\hline Mode of delivery, $\mathrm{n}(\%) \mathrm{C} / \mathrm{S}$ & $180(54.9)$ & $39.2 \pm 1.4$ \\
\hline NVD & $3214 \pm 492$ & $1950-4810$ \\
\hline Gestational time, weeks & $3368 \pm 570$ & $2130-4960$ \\
\hline Birth weight, g & $12.5 \pm 8.0$ & $1-28$ \\
\hline Weight, at admission to the hospital, g & \\
\hline Age, at admission to the hospital, days & & 352 \\
\hline
\end{tabular}




\begin{tabular}{|l|l|l|}
\hline Fever $\left({ }^{\circ} \mathrm{C}\right)$ & $38.3 \pm 0.4$ & $38-40$ \\
\hline Length of stay in hospital, days & $7.4 \pm 3.7$ & $2-22$ \\
\hline C/S: Cesarean Section; NVD: Normal Vaginal Delivery &
\end{tabular}

Table 2: The final diagnosis of all febrile neonates

\begin{tabular}{|c|c|c|}
\hline Category of Diagnosis & & n (\%) \\
\hline $\begin{array}{l}\text { Unclassified-unknown Reason of } \\
\text { Fever }\end{array}$ & & $\begin{array}{l}143 \\
(43.6)\end{array}$ \\
\hline Urinarytractinfection & & $51(15.5)$ \\
\hline Only dehydration & & $46(14)$ \\
\hline Bacteremia & & $19(5.8)$ \\
\hline Pneumonia & & $18(5.5)$ \\
\hline Viral Respiratory Tract Infection & & $13(4.0)$ \\
\hline Meningitis & & $12(3.7)$ \\
\hline \multirow{4}{*}{ Complex Infection } & $\begin{array}{l}\text { Urinary Tract Infection } \\
\text { +Dehydration }\end{array}$ & 6 \\
\hline & Bacteremia+Pneumonia & $4(6.1)$ \\
\hline & Bacteremia+Dehydration & 4 \\
\hline & $\begin{array}{l}\text { Bacteremia+Urinary Tract } \\
\text { Infection }\end{array}$ & 4 \\
\hline
\end{tabular}

\begin{tabular}{|l|l|l|}
\hline & $\begin{array}{l}\text { Pneumonia+Urinary Tract } \\
\text { Infection }\end{array}$ & 2 \\
\hline Otitismedia & & $2(0.6)$ \\
\hline Gastroenteritis & & $2(0.6)$ \\
\hline Soft Tissue Infection & & $2(0.6)$ \\
\hline Total & & $\mathbf{3 2 8 ( 1 0 0 )}$ \\
\hline
\end{tabular}

The final diagnosis of the febrile neonates are presented in table 2. During the study period, the overall rate of SBI was $38.4 \%(n=126)$. The most common final diagnosis was febrile illness without any detectable reason, which accounted $43.6 \%$ of all cases. Urinary tract infection, dehydration, and bacteremia were the next common diagnoses, accounting for $15.5 \%, 14 \%$, and $5.8 \%$, respectively. Dehydration was detected in 56 neonates, 46 of them were diagnosed only dehydrated, whereas 10 also had SBI. The characteristics and laboratory results of neonates who had SBI or did not have SBI are compared in table 3.

Table 3: A comparison of the characteristics according to presence or absence of SBI (serious bacterial infection)

\begin{tabular}{|c|c|c|c|c|c|c|}
\hline & & \multicolumn{2}{|l|}{ SBI $(+)(n=126)$} & \multicolumn{2}{|c|}{ SBI(-) $(n=202)$} & \multirow{3}{*}{$\begin{array}{l}\mathbf{p} \\
0.045\end{array}$} \\
\hline & & \multicolumn{4}{|l|}{$\mathrm{n} \%$} & \\
\hline Gender & Male & 77 & 61.6 & 107 & 52.9 & \\
\hline Weight Loss & Yes & 10 & 7.9 & 46 & 22.8 & $<0.001$ \\
\hline Mode of delivery & NSD & 66 & 52.4 & 114 & 56.4 & 0.375 \\
\hline \multirow[t]{2}{*}{ Start to Antibiotics } & Yes & 126 & 100 & 140 & 69.3 & $<0.001$ \\
\hline & & \multicolumn{3}{|c|}{ Mean \pm Standard deviation } & & \\
\hline Gestational time & weeks & $39.0 \pm 1.3$ & & $39.3 \pm 1.4$ & & 0.012 \\
\hline Birth Weight & $\mathrm{g}$ & $3236 \pm 518$ & & $3192 \pm 466$ & & 0.704 \\
\hline Age at Admission to the Hospital & days & $13.5 \pm 7.8$ & & $11.5 \pm 8.1$ & & 0.017 \\
\hline Weight at Admission to the Hospital & $\mathrm{g}$ & $3443 \pm 574$ & & $3294 \pm 557$ & & 0.007 \\
\hline Fever & ${ }^{\circ} \mathrm{C}$ & $38.3 \pm 0.4$ & & $38.3 \pm 0.4$ & & 0.761 \\
\hline Length of stay in hospital & days & $9.8 \pm 3.5$ & & $5.0 \pm 2.0$ & & $<0.001$ \\
\hline \multicolumn{7}{|l|}{ Laboratory Results } \\
\hline WBC & $($ cells $/ \mu \mathrm{L})$ & $12123 \pm 5255$ & & $11025 \pm 4204$ & & 0.279 \\
\hline Platelets & $\left(\right.$ cells $\left./ \mathrm{mm}^{3}\right)$ & $323493 \pm 113544$ & & $287237 \pm 90095$ & & 0.005 \\
\hline CRP & $\mathrm{nmol} / \mathrm{L}$ & $209.5 \pm 333.3$ & & $47.6 \pm 57.1$ & & $<0.001$ \\
\hline $\mathrm{I} / \mathrm{M}$ ratio $\mathrm{n}(\%)$ & $>0.2$ & $28(17.1)$ & & $10(6.1)$ & & 0.002 \\
\hline ANC n(\%) & $>1500$ cells $/ \mu \mathrm{L}$ & $32(36.0)$ & & $21(20.8)$ & & 0.02 \\
\hline
\end{tabular}


The pathogens detectedin febrile neonates with SBI are enlisted in table 4. Bacterial growth in culture detected at 97 patients in our study. Most common identified bacteria were

Escherichia coli (E.Coli) in 19 cases, Methicillin-Resistant Coagulase-Negative Staphylococci (MRCoNS) in 16 cases and Enterococcus in 14 cases.

Table 4: The distribution of causative bacterial pathogens in SBI

\begin{tabular}{|c|c|c|}
\hline & Causative pathogen & $\mathbf{n}$ \\
\hline \multirow[t]{8}{*}{ Urinary tract infection $n=51$ (15.5) } & Escherichia coli & 15 \\
\hline & Enterococcus & 10 \\
\hline & Klebsiella species & 8 \\
\hline & Enterobacter & 7 \\
\hline & CoNS & 6 \\
\hline & Proteus mirabilis & 2 \\
\hline & Undefined Gram-negative pathogen & 2 \\
\hline & Citrobacter werkmanii & 1 \\
\hline \multirow[t]{4}{*}{ Bacteremia $n=19(5.8)$} & MRCoNS & 7 \\
\hline & CoNS & 3 \\
\hline & Escherichia coli & 2 \\
\hline & $\begin{array}{l}\text { Enterococcus, Klebsiella species, N. Meningitidis, Enterobacter, S. } \\
\text { warneri, S. capitis, Enteric Gram-negative rods. }\end{array}$ & $1^{*}$ \\
\hline \multirow[t]{5}{*}{ Combined infection $n=20(6.1)$} & MRCoNS & 6 \\
\hline & CoNS & 5 \\
\hline & Klebsiella species & 4 \\
\hline & Escherichia coli & 2 \\
\hline & Enterococcus & 3 \\
\hline \multirow[t]{5}{*}{ Meningitis $n=12(3.7)$} & MRCoNS & 3 \\
\hline & K. pneumonia & 2 \\
\hline & CoNS & 1 \\
\hline & Pseudomonas & 1 \\
\hline & Undefined & 5 \\
\hline
\end{tabular}

A total of 328 urine specimens were collectedby the urinary catheter of the 51 infants diagnosed with UTI, only $60.1 \%$ had pyuria. The most common pathogens isolated from urine cultures was E.coli. The most common pathogen was MRCoNS in bacteremia,complex infection, and meningitis (Table 4). Among the 124 neonates, in whom lumbar puncture was performed, 12 had leucocyte count $>10$ and 7 showed positive CSF (Cerebrospinal Fluid) culture. Rapid viral antigen test was performed in 48 neonateswith respiratory tract infection, and 13 were detected positive (RSV=8 cases, Influenza $=5$ cases).

ROC curve analysis wascarried outto determinethe optimal CRP cut-offvalues and WBC counts for detecting SBI. A significant cut-off value could not be determined for CRP (AUC: 0.664 ) $95 \% \mathrm{Cl}: 0.604-0.723$ and WBC (AUC: 0.535 ) $95 \% \mathrm{Cl}$ : 0.472-0.597 (Figures 2A and 2B). 


\section{Eligible neonate $\mathrm{n}: 424$}

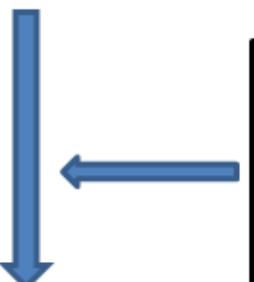

\section{Excluded from study \\ No permission: 31 case \\ İnsufficient data: 21 case \\ In correct criterias: 32 case}

\section{Study group \\ $\mathrm{n}: 328$}

\section{SBI positive} n:126

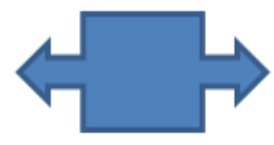

\section{SBI negative n:202}

Obtained pathogen organism n:97 Without isolated pathogen n: 29

\section{Undefined n:143 \\ Only Dehydration n:46 \\ Proven Viral İnfection: n:13}

Figure 1: The flow diagram of the study

RoC Curve

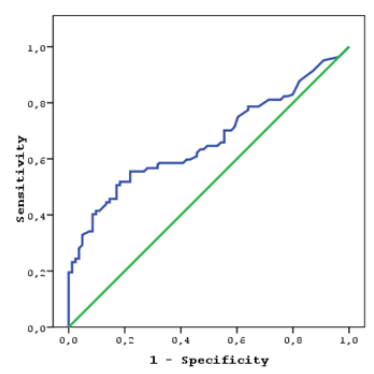

Figure 2: Receiver operating characteristics curve analysis for A) CRP (AUC: 0.664) 95\% Cl: 0.604-0.723; B) white blood cell count (AUC: 0.535 ) $95 \% \mathrm{Cl}$ : 0.472-0.597 for predicting severe bacterial infections.

\section{Discussion}

Fever is a common symptom in neonate visiting outpatient clinics. The causes of fever in these neonates vary from dehydration, mild viral infection to serious bacterial infections which are progressive and lead to severe morbidity or mortality. Evaluation and treatment of febrile neonatesvaried widely among the different centers [11]. These differences demonstrate the deficiency of and highlight the necessity for national or international guidelines for the assessment of fever in this age group.

Given this, the overall prevalence of $\mathrm{SBI}$ is high in neonates; thus, most experts would supportthe approach of a full sepsis evaluation and hospitalization [12]. Nevertheless, the studies on the treatment approaches for febrile neonate suggested amodification of management models with theaddition of CRP and erythrocyte sedimentation rate, and also recommended inhospital treatments of theneonates with low-risk factors and follow-up without an antibiotic treatment $[13,14]$. The current status is none of the markers alone or in combination display satisfactory sensitivity or precision for the diagnosis of $\mathrm{SBI}$ in well-appearing febrile neonates, and there is noconsensus about the assessment and management of outpatient newborns with fever.

The prevalence of $\mathrm{SBI}$ in infants of $<3$ months of age with fever is about $7.1-19.7 \%$. This is higher in infants aged $0-28$ days $(9-28 \%)$ than those $2-3$ months old $(7.1 \%)[2-9,15,16]$. We found the overall rate of $\mathrm{SBI}$ was high (38.4\%) and our findings confirmed that $\mathrm{SBI}$ was seen more frequent in the neonatal period.

$\mathrm{UTI}$ is the most common SBI in infants younger than 90 days age, which was found in $3.0-11.0 \%$ of febrile infants in various reports [17]. On the other hand, UTI was found higher and reported that 14-21.3 percent in febrile neonatesthat means UTI affects approximately 1 in 6 febrile neonates[2-11,18]. In our 
study, UTI incidence was found similarly the most common etiology of fever in neonatal period.

In the studies evaluating low-risk criteria of febrile infants, UTI was the most frequently missed SBI [19]. The sensitivity of urinalysis and urine dipstick test for determination of UTI is low approximately 60 to $79 \%$ [18]. Similarly, in our study, only $60.1 \%$ of UTI cases were positive in standard urinalysis. Thus standard urinalysis was found to be insufficient in the identification of UTI during neonatal period.

Pathogens of UTI were $E$. coli in $81 \%$ and $K$. pneumoniae in $19 \%$ in infants less than 3 months [20]. In febril neonates, the most common uropathogens were found Escherichia coli (71\%), Enterococcus (10\%) and Klebsiella sp. (10\%) [18]. We were cultured E.coli (15/51) as the most common pathogen in UTI, but in our study different pathogens especially Enterecocus, Enterobacter and CoNS were found high proportion in febril outpatient newborns. This situation was attributed to the different colonizations of different societies in communityacquired infections.

Infants less than 3 months with bacteremia, 54\% were caused by group B Streptococus, $23 \%$ by E. coli [20]. There are not a sufficient source for pathogens causing bacterial infections in only febrile newborns. Gram positive pathogens MRCoNs and CoNS, near to $50 \%$ percent causative bacteremia in our study.

Bacterial pathogens were not detected mostly in babies apply with fever and this situation was identified as viral syndrome by many authors and fever attributed to viral syndrome in their studies with a rate of $60.2 \%$ and $72 \%$ respectively $[2,21]$. Viral culture or rapid viral antigen analysis were not done in both studies.

Recent meta-analysis about RSV and SBI demonstrated that rates of positive SBI are not different between febrile neonates with or without positive RSV and respiratory viral infection status is not an accurate clinical determinant in distinguishing $\mathrm{SBI}$ risk in febril neonates [22]. On the contrary, concomitant confirmed viral infections reduce the probability of SBI from $12.3 \%$ to $4.2 \%$ and bacteremia from $2.7 \%$ to $1 \%$ [23].

It is suggested that full septic evaluations are not necessary in nontoxic appearing infants with a positive RSV test [24]. In our study, we could not detect any reason for the fever in about $43.6 \%$ babies. Among the 48 babies, with whom we conducted rapid antigen test, 13 were detected virus antigen (RSV + Influenza). None of the low-risk protocols include a viral testing in the evaluation of the febrile infant. However, our study suggests that viral antigen screening can be useful in guiding the management of febrile neonates similar to other age groups.

The need for lumbar puncture in infants with fever is still a debatable issue. Previous studies on $<90$ days old babies reported the rate of bacterial meningitis and aseptic meningitisas $0.2 \%$ and $14.4 \%$, respectively [25]. In the studies, where only neonates were included, the rate of bacterial meningitis was $0.5-4.4 \%[2,11-13]$. Lumbar puncture and CSF analysis werenot done routinely in the mentioned studies.

Certainincidences of bacteremia and meningitis were missed in neonates who were analysed according to definition of low- risk for SBI $[15,16]$. In a comprehensive review on this subject,it was stated that whether a lumbar puncture is required to all febrile infants or which parameter can predict the need for lumbar puncture cannot be answered definitely [17]. Our study revealed a higher rate of meningitis in newborns than the infants between ages of 1-3 months. In our study, lumbar puncture was conducted according to the ward's policy, which suggests performing a lumbar puncture for every infant if theneurologic finding is positive or without thefocus of fever. By this method, we believe that undetected cases of meningitis were reduced as much as possible.

The earlier studies proposed that, in the assessment of $<90$ days old febrile infants, the diagnostic data for various laboratory measures can be employed by using individual thresholds of the following tests: urinanalysis (microscopy, dipstick), WBC, erythrocyte sedimentation rate (ESR), $A B C$, absolute neutrophil count (ANC), procalcitonin and Interleukin- 6 [26]. The overall accuracy of ANC and $A B C$ was greater than that for WBC [14]. The use of CRP showed higher overall accuracy than WBC, ANC, and procalcitonin in accurately diagnosing infants with and without SBI [9,27]. The combination of procalcitonin with urinalysis was reported as more sensitive for identifying SBI in babies between 2 and 60 days old [28]. Recently, Nosrati reported that CRP was the only parameter found to be significantly associated with SBI (odds ratio, 1.042; 95\% confidence interval $\mathrm{Cl}: 1.028-1.056)$ in febrile infants [25].

However, in this study, the cut-off value for CRP was determined as $2 \mathrm{mg} / \mathrm{dl}$ which led to higher specificity to this parameter to identify SBI. On the contrary of these information, it was notified that "no marker could be totally rule out SBI in febrile infants less than 3 months of age" $[26,29,30]$. In our study, which included only neonates, a reliable cut-off value could not be determined for CRP and WBC.

In this prospective observational study, which included 328 febrile newborns, determined that SBI incidence in febrile infants was encountered at pretty high rates. Most common focus detected in newborn babies with SBI was UTI and the most common pathogen was $E$. Coli. We found Gram positive pathogens were more common than in infants less than 90 days. A reliable cut-off value for CRP and WBC for detection SBI could not be determined.

\section{References}

1. Greenhow TL, Hung YY, Pantel RH (2016) Management and Outcomes of Previously Healthy, Full-Term, Febrile Infants Ages 7 to 90 Days. Pediatrics 138: e20160270.

2. Marom R, Sakran W, Antonelli J, Horovitz Y, Zarfin Y, et al. (2007) Quick identification of febrile neonates with low risk for serious bacterial infection: an observational study. Arch Dis Child Fetal Neonatal Ed 92: F15-18.

3. Schwartz S, Raveh D, Toker O, Segal G, Godovitch N, et al. (2009) A week-by-week analysis of the low-risk criteria for serious bacterial infection in febrile neonates. Arch Dis Child 94: 287-292.

4. Bilavsky E, Yarden BH, Amir J, Ashkenazi S (2010) Should complete blood count be part of the evaluation of febrile infants aged $\leq 2$ months? Acta Paediatr 99: 1380-1384. 
5. Garcia S, Mintegi S, Gomez B, Barron J, Pinedo M, et al. (2012) Is 15 days an appropriate cut-off age for considering serious bacterial infection in the management of febrile infants? Pediatr Infect Dis J 31: 455-458.

6. Pulliam PN, Attia MW, Cronan KM (2001) C-reactive protein in febrile children 1 to 36 months of age with clinically undetectable serious bacterial infection. Pediatrics 108: 1275-1279.

7. Baker MD, Bell LM (1999) Unpredictability of serious bacterial illness in febrile infants from birth to 1 month of age. Arch Pediatr Adolesc Med 153: 508-511.

8. Galetto-Lacour A, Zamora SA, Gervaix A (2003) Bedside procalcitonin and $\mathrm{C}$-reactive protein tests in children with fever without localizing signs of infection seen in a referral center. Pediatrics 112: 1054-1060.

9. Brown L, Shaw T, Wittlake WA (2005) Does leucocytosis identify bacterial infections in febrile neonates presenting to the emergency department? Emerg Med J 22: 256-259.

10. McWilliam S, Riordan A (2010) How to use: C-reactive protein. Arch Dis Child EducPract Ed 95: 55-58.

11. Jain S, Cheng J, Alpern ER, Thurm C, Schroeder L, et al. (2014) Management of febrile neonates in US pediatric emergency departments. Pediatrics 133: 187-195.

12. Baraff LJ, Bass JW, Fleisher GR, Klein JO, McCracken GH Jr, et al. (1993) Practice guideline for the management of infants and children 0 to 36 months of age with fever without source. Agency for Health Care Policy and Research. Ann Emerg Med 22: 1198-1210.

13. Chiu CH, Lin TY, Bullard MJ (1997) Identification of febrile neonates unlikely to have bacterial infections. Pediatr Infect Dis J 16: 59-63.

14. Bressan S, Andreola B, Cattelan F, Zangardi T, Perilongo G, et al. (2010) Predicting severe bacterial infections in well-appearing febrile neonates: laboratory markers accuracy and duration of fever. Pediatr Infect Dis J 29: 227-232.

15. Chiu CH, Lin TY, Bullard MJ (1994) Application of criteria identifying febrile outpatient neonates at low risk for bacterial infections. Pediatr Infect Dis J 13: 946-949.

16. Chiu CH, Lin TY (1998) Application of the Rochester Criteria in febrile neonates. Pediatr Infect Dis J 17: 267-269.

17. Hui C, Neto G, Tsertsvadze A, Yazdi F, Tricco AC, et al. (2012) Diagnosis and management of febrile infants (0-3 months). Evid Rep Technol Assess (Full Rep) 205: 1-297.

18. Bonadio W, Maida G (2014) Urinary tract infection in outpatient febrile infants younger than 30 days of age: a 10 -year evaluation. Pediatr Infect Dis J 33: 342-344.
19. Dagan R, Powell KR, Hall CB, Menegus MA (1985) Identification of infants unlikely to have serious bacterial infection although hospitalized for suspected sepsis. J Pediatr 107: 855-860.

20. Shin SH, Choi CW, Lee JA, Ee-Kyung Kim, Eun Hwa Choi, et al. (2009) Risk factors for serious bacterial infection in febrile young infants in a community referral hospital. J Korean Med Sci 24: 844-848.

21. Baker MD, Bell LM, Avner JR (1993) Outpatient management without antibiotics of fever in selected infants. N Engl J Med 329: 1437-1441.

22. Bonadio W, Huang F, Nateson S, Okpalaji C, Kodsi A, et al. (2016) Meta-analysis to Determine Risk for Serious Bacterial Infection in Febrile Outpatient Neonates With RSV Infection. Pediatr Emerg Care 32: 286-289.

23. Byington CL, Enriquez FR, Hoff C, Tuohy R, Taggart EW, et al. (2004) Serious bacterial infections in febrile infants 1 to 90 days old with and without viral infections. Pediatrics 113: 1662-1666.

24. Titus MO, Wright SW (2003) Prevalence of serious bacterial infections in febrile infants with respiratory syncytial virus infection. Pediatrics 112: 282-284.

25. Nosrati A, Ben Tov A, Reif S (2014) Diagnostic markers of serious bacterial infections in febrile infants younger than 90 days old. Pediatr Int 56: 47-52.

26. Zarkesh M, Sedaghat F, Heidarzadeh A, Tabrizi M, Bolooki-MK, et al. (2015) Diagnostic value of IL-6, CRP, WBC, and absolute neutrophil count to predict serious bacterial infection in febrile infants. Acta Med Iran 53: 408-411.

27. Bilavsky E, Yarden-Bilavsky H, Ashkenazi S, Amir J (2009) C-reactive protein as a marker of serious bacterial infections in hospitalized febrile infants. Acta Paediatr 98: 1776-1780.

28. Woelker JU, Sinha M, Christopher NC, Powell KR (2012) Serum procalcitonin concentration in the evaluation of febrile infants 2 to 60 days of age. Pediatr Emerg Care 28: 410-415.

29. Stein M, Schachter-Davidov A, Babai I, Tasher D, Somekh E (2015) The accuracy of C-reactive protein, procalcitonin, and s-TREM-1 in the prediction of serious bacterial infection in neonates. Clin Pediatr (Phila) 54: 439-444.

30. Bressan S, Andreola B, Cattelan F, Zangardi T, Perilongo G (2010) Predicting severe bacterial infections in well-appearing febrile neonates: laboratory markers accuracy and duration of fever. Pediatr Infect Dis J 29: 227-232. 